\title{
Evaluation of extraction methods from paraffin wax embedded tissues for PCR amplification of human and viral DNA
}

\author{
P K S Chan, D P C Chan, K-F To, M Y Yu, J L K Cheung, A F Cheng
}

\begin{abstract}
Aim-To evaluate the efficiency of phenol/ chloroform, microwave, and Qiagen spin column based DNA extractions from paraffin wax embedded tissue for use in the polymerase chain reaction (PCR). In addition, to assess the reliability of amplifying a housekeeping gene to indicate successful viral DNA extraction.

Methods-DNA samples extracted from 20 blocks of cervical carcinoma tissues using the three methods were subjected to PCRs targeting $509 \mathrm{bp}$ and $355 \mathrm{bp}$ of the $\beta$ globin gene, and $450 \mathrm{bp}$ and $150 \mathrm{bp}$ of human papillomavirus (HPV) DNA.

Results-Microwave extraction showed the highest positive rate for $\beta$ globin PCR, whereas the spin column method was the most efficient for HPV DNA extraction. When the 509 bp $\beta$ globin and 450 bp HPV PCR results were correlated, two of 10 , eight of 12 , and nine of $10 \beta$ globin positive extractions prepared by means of the phenol/chloroform, microwave, and spin column methods, respectively, yielded HPV DNA of the expected size. For the $\beta$ globin negative samples, HPV was detected in three of 10 , two of eight, and four of 10 samples.

Conclusions-HPV DNA extraction was most efficient using the Qiagen spin column and had the highest positive predictive value when a housekeeping gene was used as an indicator of successful viral DNA extraction; the phenol/ chloroform method was the least efficient. The potential drawbacks of some extraction methods when using a human housekeeping gene to assess the quality of viral DNA extraction need to be considered. (F Clin Pathol 2001;54:401-403)
\end{abstract}

Keywords: cervical cancer; DNA extraction; polymerase chain reaction

Paraffin wax embedded tissues are a valuable source of DNA for analysis. The traditional method of purifying DNA from archival tissues using xylene dewaxing followed by phenol/ chloroform purification is labourious and requires multiple steps that are prone to cross contamination. Recently, alternative approaches have been used. ${ }^{1-3}$ In most studies, the success of DNA extraction is assessed by amplifying a fragment of a housekeeping gene, and the number of positive samples are regarded as a denominator when calculating the prevalence of target pathogens. Whether such an assessment can guarantee the retention of an equivalent length of DNA of the target pathogen has not been fully elucidated. In our study, three methods were applied on a series of paraffin wax embedded tissues to compare their efficiency for purifying human and viral DNA, and to assess the reliability of using a housekeeping gene as an indicator for successful viral DNA extraction.

\section{Methods}

STUDY SAMPLES

Twenty blocks of formalin fixed, paraffin wax embedded cervical squamous cell carcinoma stored for four to six years were analysed. For each case, four $5 \mu \mathrm{m}$ thick slices were cut in triplicate. The area to be sectioned was examined carefully to ensure the inclusion of tumour tissue and that an equal amount of tissue was included in each set. Three different DNA purification methods were performed for each case. Thorough cleansing was performed between cases and a new set of cutting instruments was used for each case. All polymerase chain reactions (PCRs) were carried out using stringent precautions to avoid cross contamination. DNA extraction, PCR reagent preparation, amplification, and amplicon analysis were performed in separate rooms. Disposable aeroguard pipette tips were used throughout. A negative control was included after each fifth sample, and this included the DNA extraction and PCR reagents. In addition, all positive samples were repeated in a separate PCR run and all were reproducible.

\section{PHENOL/CHLOROFORM EXTRACTION}

Procedures were performed according to a published protocol. ${ }^{4}$ After dewaxing with two washes of xylene, $1 \mathrm{ml}$ of $100 \%$ ethanol was added to remove residual xylene. The tissues were dried at $37^{\circ} \mathrm{C}$ for two hours, and resuspended in $300 \mu \mathrm{l}$ of digestion buffer (50 mM Tris, $5 \mathrm{mM}$ EDTA, pH 8, and $300 \mu \mathrm{g} /$ $\mathrm{ml}$ proteinase $\mathrm{K}$ ) and incubated overnight at $56^{\circ} \mathrm{C}$. The digested suspension was mixed with $300 \mu \mathrm{l}$ of $\mathrm{phenol} / \mathrm{chloroform} /$ isoamyl alcohol $(25 / 24 / 1)$, followed by centrifugation to obtain the aqueous phase. After repeating these purification steps twice, $300 \mu \mathrm{l}$ of chloroform/ isoamyl alcohol $(24 / 1)$ was added and centrifuged for one minute at $4^{\circ} \mathrm{C}$. Sodium acetate (final concentration $0.25 \mathrm{M}, \mathrm{pH} 5.2$ ) and $600 \mu \mathrm{l}$ of $95 \%$ ethanol were added for an overnight DNA precipitation at $-20^{\circ} \mathrm{C}$. The DNA pellet was collected by centrifugation for 30 minutes at $4^{\circ} \mathrm{C}$, washed with $70 \%$ ethanol, air dried at room temperature, and resuspended in $50 \mu \mathrm{l}$ of double distilled water. 
MICROWAVE EXTRACTION

The protocol was based on a published method. ${ }^{1}$ Microcentrifuge tubes containing tissues and $200 \mu \mathrm{l}$ of digestion buffer $(50 \mathrm{mM}$ Tris/HCl, $\mathrm{pH} 8.5,1 \mathrm{mM}$ EDTA, and $0.5 \%$ Tween 20) were tightly capped and subjected to high power microwave irradiation for 1.5 minutes, with the irradiation time split into 15 second segments to prevent overboiling. After centrifugation for 10 minutes at room temperature, the solid paraffin wax ring that formed above the buffer was removed, and the tissue pellet was digested in $200 \mu \mathrm{l}$ of digestion buffer containing $200 \mu \mathrm{g} / \mathrm{ml}$ proteinase $\mathrm{K}$ at $56^{\circ} \mathrm{C}$, overnight. After centrifugation at room temperature, the DNA containing supernatant was collected and boiled for 10 minutes at $95^{\circ} \mathrm{C}$ to denature residual proteinase and proteins.

QIAGEN SPIN COLUMN EXTRACTION

The commercial QIAamp DNA Mini Kit (Qiagen, Hilden, Germany) was used according to the manufacturer's protocol. The tissues were dewaxed with two washes of xylene, followed by the addition of $1 \mathrm{ml}$ of $100 \%$ ethanol to remove residual xylene. After dewaxing, tissues were digested with $200 \mu \mathrm{l}$ of ALT buffer containing proteinase $\mathrm{K}$ at $200 \mu \mathrm{g} / \mathrm{ml}$ overnight at $56^{\circ} \mathrm{C}$. After digestion, $200 \mu \mathrm{l}$ of $\mathrm{AL}$ buffer was added and incubated at $70^{\circ} \mathrm{C}$ for $10 \mathrm{~min}$ utes, followed by mixing with $200 \mu \mathrm{l}$ of $100 \%$ ethanol. The solution was transferred into a spin column, centrifuged for one minute, and washed with AW1 and AW2 buffers. DNA was eluted with $200 \mu \mathrm{l}$ of $\mathrm{AE}$ buffer preheated to $70^{\circ} \mathrm{C}$, and further incubated at $70^{\circ} \mathrm{C}$ for five minutes before collection by centrifugation. The buffers and the proteinase were provided in the extraction kit.

\section{PCR AMPLIFICATION}

$\beta$ globin PCR

Extracted preparations were subjected to two sets of PCR targeting a $509 \mathrm{bp}$ fragment (PC03/PC07) and a $355 \mathrm{bp}$ fragment ( $\beta$ globin $\mathrm{A} / \beta$ globin $\mathrm{B}$ ) of the $\beta$ globin gene. ${ }^{56}$ Extracts $(5 \mu \mathrm{l})$ were amplified in a $50 \mu \mathrm{l}$ reaction mixture containing $10 \mathrm{mM}$ Tris/ $\mathrm{HCl}, \mathrm{pH} 8.3$, $50 \mathrm{mM} \mathrm{KCl}, 1.5 \mathrm{mM} \mathrm{MgCl}, 200 \mu \mathrm{M}$ of each dNTP, $0.125 \mu \mathrm{M}$ of each primer, and $1.5 \mathrm{U}$ of Taq polymerase (Pharmacia Biotech, Upsala, Sweden). The cycling conditions were initial denaturation at $94^{\circ} \mathrm{C}$ for four minutes, followed by 40 cycles of denaturation at $94^{\circ} \mathrm{C}$ for one minute, annealing at $57^{\circ} \mathrm{C}$ for one minute,

Table 1 Positive rates of human papillomavirus (HPV) PCRs according to DNA extraction methods

\begin{tabular}{llll}
\hline & & \multicolumn{2}{l}{ No. of HPV DNA positive by } \\
\cline { 3 - 4 } Extraction method & No. of samples & $\begin{array}{l}\text { MY09/11 PCR } \\
(450 \mathrm{bp})\end{array}$ & $\begin{array}{l}\text { GP5+/6+ PCR } \\
(150 \mathrm{bp})\end{array}$ \\
\hline $\begin{array}{l}\text { Phenol/chloroform } \\
509 \text { bp } \beta \text { globin PCR positive }\end{array}$ & 10 & 2 & 5 \\
509 bp $\beta$ globin PCR negative & 10 & 3 & 7 \\
$\begin{array}{l}\text { Microwave } \\
509 \text { bp } \beta \text { globin PCR positive }\end{array}$ & 12 & 8 & 10 \\
509 bp $\beta$ globin PCR negative & 8 & 2 & 2 \\
Qiagen spin column & & 9 & \\
509 bp $\beta$ globin PCR positive & 10 & 9 & 9 \\
509 bp $\beta$ globin PCR negative & 10 & 4 & 6 \\
\hline
\end{tabular}

extension at $72^{\circ} \mathrm{C}$ for 1.5 minutes, and a final extension step at $72^{\circ} \mathrm{C}$ for eight minutes. DNA extracted from lymphocytes was used as a positive control. The PCR products $(10 \mu \mathrm{l})$ were electrophoresed and visualised by ethidium bromide staining.

\section{HPV PCR}

Extracted preparations were subjected to two sets of PCR targeting a $450 \mathrm{bp}$ fragment (MY09/MY11) and a $150 \mathrm{bp}$ fragment (GP5+/ GP6+) of the L1 open reading frame (ORF) of human papillomavirus (HPV). ${ }^{78}$ The amplification conditions were the same as for the $\beta$ globin gene, except a primer concentration of $0.25 \mu \mathrm{M}$ and annealing at $55^{\circ} \mathrm{C}(\mathrm{MY} 09 / 11$ PCR) or $45^{\circ} \mathrm{C}(\mathrm{GP} 5+/ 6+\mathrm{PCR})$ were used. Formalin fixed, paraffin wax embedded HeLa cells that contain HPV-18 were subjected to each of the extraction methods and served as positive controls for HPV PCRs. The HPV types in positive samples were characterised by PCRs specific for the E7 encoding regions of HPV types 16, 18, 31, 33, 35, 52, and 58. ${ }^{9}$ The amplicon size of these type specific PCRs ranged from 100 to $130 \mathrm{bp}$.

\section{Results}

$\beta$ GLOBIN PCR

The positive rates of the phenol/chloroform, microwave, and Qiagen spin column methods were, $50 \%, 60 \%$, and $50 \%$, respectively, for the 509 bp $\beta$ globin PCR; for the 355 bp $\beta$ globin PCR these figures were $90 \%, 95 \%$, and $95 \%$.

HPV PCR

The positive rates of phenol/chloroform, microwave, and Qiagen spin column methods were $25 \%, 50 \%$, and $65 \%$, respectively, for the $450 \mathrm{bp}$ HPV PCR; for the $150 \mathrm{bp} \mathrm{HPV} \mathrm{PCR}$ these figures were $60 \%, 60 \%$, and $75 \%$ (table 1 ). When the results of the $509 \mathrm{bp} \beta$ globin and 450 bp HPV PCRs were correlated, two of 10, eight of 12, and nine of 10 of the phenol/ chloroform, microwave, and Qiagen spin column extracted $\beta$ globin PCR positive samples, respectively, yielded a positive result in HPV PCR; for the $\beta$ globin PCR negative samples these figures were three of 10 , two of eight, and four of 10 (table 1 ).

HPV TYPE

Of the 18 samples that were positive for HPV DNA, 10 were HPV-16, four were HPV-58, two were HPV-33, one was HPV-18, and the other was HPV-31. In three of the 18 samples, HPV DNA was only detected by the $150 \mathrm{bp}$ GP5+/6+ HPV PCR and these samples contained HPV-16, HPV-18, and HPV-33. Table 2 shows the distribution of HPV types with respect to $\beta$ globin PCR results. The two most commonly detected HPV types (16 and 58 ) were found in both $\beta$ globin PCR positive and negative samples, and did not show a significant difference in distribution (HPV-16, $\mathrm{p}=0.209 ; \mathrm{HPV}-58, \mathrm{p}=1.0$, by two tailed Fisher's exact test).

\section{Discussion}

Each of the three methods compared has its own merits and pitfalls. Phenol/chloroform 
Table 2 Distribution of human papillomavirus (HPV) types according to $\beta$ globin PCR results

No. of samples positive by MY09/11, 450 bp HPV PCR

\begin{tabular}{lllll}
\cline { 2 - 4 } 509 bp $\beta$ globin PCR & $H P V-16$ & $H P V-31$ & $H P V-33$ & $H P V-58$ \\
\hline Positive & 2 & & & \\
Phenol/chloroform & 6 & 0 & 0 & 0 \\
Microwave & 6 & 0 & 0 & 2 \\
Qiagen spin column & 14 & 0 & 0 & 3 \\
Subtotal & & & 0 & 5 \\
Negative & 1 & 1 & 0 & 1 \\
Phenol/chloroform & 1 & 0 & 0 & 1 \\
Microwave & 2 & 0 & 1 & 1 \\
Qiagen spin column & 4 & 1 & 1 & 3 \\
Subtotal & & & \\
\hline
\end{tabular}

extraction uses inexpensive, readily available reagents but is labourious. The microwave method does not require the use of xylene for dewaxing or other dangerous chemicals for extraction. Although this method has been reported to be efficient for extracting DNA up to $400-600 \mathrm{bp},{ }^{1}$ data on its comparison with other methods are limited. The Qiagen spin column extraction protocol is the simplest, but is the most costly among the three.

When the PCR positive rates for the single copy $\beta$ globin gene were compared, microwave extraction performed most efficiently, with $60 \%$ for the $509 \mathrm{bp} \mathrm{PCR}$ and $95 \%$ for the $355 \mathrm{bp}$ PCR. In contrast, the phenol/ chloroform method was least satisfactory, with positive rates of $50 \%$ for the $509 \mathrm{bp}$ PCR and $90 \%$ for the $355 \mathrm{bp} \mathrm{PCR}$. The inferior performance of phenol/chloroform extraction was also reflected in the HPV PCRs, where only $25 \%$ of phenol/chloroform treated samples showed positive results for the $450 \mathrm{bp}$ HPV DNA versus $50 \%$ and $65 \%$ with the other two methods.

When the reliability of using a housekeeping human gene, $\beta$ globin, as an indicator for the successful extraction of an equivalent length of target viral DNA was analysed, the Qiagen spin column extraction method showed the highest positive predictive value, with nine of 10 $\beta$ globin PCR positive samples yielding an expected length of HPV DNA. The remaining negative sample, which was also negative by the shorter (150 bp) HPV PCR, might in fact be a true HPV negative sample or, alternatively, the L1 ORF might have been disrupted during integration. The phenol/chloroform method was again the least satisfactory, with only two of 10 samples yielding HPV DNA of the expected size; in addition, the eight "negative" samples were shown to contain the 450 bp HPV DNA by other extraction methods. Apart from the better positive predictive value, the Qiagen spin column method also provided the highest positive rate for both HPV PCRs examined.

Our results indicate that, depending upon the extraction method, a positive PCR result of a human housekeeping gene does not necessarily guarantee the successful extraction of a corresponding length of target viral DNA. These observations suggest that the prevalence of HPV DNA in cervical cancer may well be underestimated, particularly in the early days when phenol/chloroform extraction was the most commonly used method. This is in line with a recent study that reported $99.7 \%,{ }^{9}$ in contrast to previous reports of $\sim 90 \%,{ }^{10}$ of cervical cancer tissues contain HPV. Alternatively, we also found that a few $\beta$ globin PCR negative samples did contain amplifiable HPV DNA. Such a discrepancy could result from the presence of more copies of HPV DNA in each cell as compared with the $\beta$ globin gene. In addition, the existence of episomal circular HPV DNA might account for the difference. We also attempted to evaluate whether the type of HPV might account for the discrepancy between $\beta$ globin gene and HPV DNA extraction, and no significant difference in distribution was observed. However, it should be noted that very few samples were positive for non-HPV-16 types in our study.

Overall, our results showed that the microwave method has advantages in terms of ease of performance, expense, and quality of extracted DNA when used for single copy human gene extraction (but not for viral DNA extraction). The Qiagen spin column, although it is the most expensive, was the most efficient for viral DNA extraction and had the highest positive predictive value when a housekeeping gene was used to assess the quality of the extracted DNA. The potential drawbacks in using a human housekeeping gene to assess the quality of extracted viral DNA need to be considered. Nevertheless, the use of a positive reaction control is essential if meaningful results are to be obtained. If a sample is negative for both the control and viral DNA amplifications, it cannot be considered as being negative for the virus, but must instead be excluded from the data analysis.

The study was supported by the Lee Hysan Foundation Research Grant and the Endowment Fund Research Grant 1998/1999 (CA10830) from United College, The Chinese University of Hong Kong.

1 Banerjee SK, Makdisi WF, Weston AP, et al. Microwavebased DNA extraction from paraffin-embedded tissue for PCR amplification. Biotechniques 1995;18:768-73.

2 Howe JR, Klimstra DS, Cordon-Cardo C. DNA extraction from paraffin-embedded tissues using a salting-out procedure: a reliable method for PCR amplification of archival material. Histol Histopathol 1997;12:595-601.

3 Pinto AP, Villa LL. A spin cartridge system for DNA extraction from paraffin wax embedded tissues. Mol Pathol 1998; 51:48-9.

4 Mahony JB. Detection of viral nucleic acids in clinical materials. In: Mahy BWJ, Kangro HO, eds. Virology methods manual. New York: Academic Press, 1996:327-8.

5 de Roda Husman AM, Snijders PJ, Stel HV, et al. Processing of long-stored archival cervical smears for human papillomavirus detection by the polymerase chain reaction. $\mathrm{Br}$ f Cancer 1995;72:412-7.

6 Lo YM, Mehal WZ, Fleming KA. In vitro amplification of hepatitis B virus sequences from liver tumour DNA and from paraffin wax embedded tissues using the polymerase chain reaction. F Clin Pathol 1989;42:840-6.

7 Ting Y, Manos MM. Detection and typing of genital human papillomavirus. In: Innis MA, Gelfond DH, Sninsky JJ, et al, eds. PCR protocol: a guide to methods and applications. San Diego, CA: Academic Press, 1990:356-67.

8 de Roda Husman AM, Walboomers JM, van den Brule AJ, et al. The use of general primers GP5 and GP6 elongated at their 3 ' ends with adjacent highly conserved sequences improves human papillomavirus detection by PCR. $7 \mathrm{Gen}$ Virol 1995;76:1057-62.

9 Walboomers JM, Jacobs MV, Manos MM, et al. Human papillomavirus is a necessary cause of invasive cervical cancer worldwide. F Pathol 1999;189:12-19.

10 Villa LL. Human papillomaviruses and cervical cancer. $A d v$ Cancer Res 1997;71:321-41. 